Research Article

\title{
Investigating the Effect of Women's Position on Advancement in the Banking Sector of Bangladesh
}

\author{
Mohammad Azizur Rahman*, Mohammad Rafiul Azam Khan
}

Department of Management Studies, Begum Rokeya University, Rangpur, Bangladesh

Article Information
Received: 15 September 2020
Revised version received: 13 October 2020
Accepted: 16 October 2020
Published: 29 October 2020
Cite this article as:
M.A. Rahman and M.R.A. Khan (2020) Int. J. Soc. Sc.
Manage. 7(4): 191-197.
DOI: $10.3126 / i j s s m . v 7 i 4.32483$
*Corresponding author
Mohammad Azizur Rahman,
Associate Professor, Management Studies, Begum
Rokeya University, Rangpur, Bangladesh
Email: azizru07@gmail.com
Peer reviewed under authority of IJSSM
(C) 2020 IJSSM, Permits unrestricted use under the
CC-By-NC license.
OPEN 0 ACCESS
This is an open access article \& it is licensed under a
Creative Commons Attribution Non-Commercial 4.0
International
(https://creativecommons.org/licenses/by-nc/4.0/)
Keywords: Gender; equity; promotion; women position

\begin{abstract}
The paper aimed at investigating the existing status and the impact of giving promotion on women's position in the banking industry. The stud was used purposive sampling on 250 employees serving the public, private and specialized banks. Normal frequency distribution as well as inferential statistics $\left(\chi^{2}\right.$-test) was applied to analyze data. For examining the effect of the number of promotion received by employees on gender position they hold chi-square test statistic was used. The study reveals that there was $85 \%$ of male and $15 \%$ of female employees worked in the banking industry. It was observed that female employees worked $16.7 \%$ of state-owned commercial (SOBs), $13.5 \%$ of private commercial (PCBs), and $13.08 \%$ of specialized (SPBs) banks (shown in Table 5). Consequently, a few numbers of female employees were at the senior level. The entry level female employees were $25 \%$ of female observed. The study also found that there was a strong association between the women's position and the number of promotion they up gradated. The study has suggested for managerial as well as policy implications the study suggested for further study to treat equally sustaining in the competitive field of financial institutions.
\end{abstract}

\section{Introduction and Research Perspectives}

In the work place men and women do have a significant role to achieve the sated goals of the organizations. The role of women worldwide is experiencing a dramatic change. Equal employment opportunities conform by the organizations. It has been embargoed that women and men have equal prestige; enjoy the same human rights; play equally valued roles through their appointment in national,

economic, social and cultural development and enjoy the benefits of this equality (Gender Policy, 2014). United Nations (UN) declared that there should have the equal compensation for a job done women (UNDP 1993). In the Constitution of Bangladesh included in the Article Section $29(1 \& 2)$, and adopted the equal opportunities in respect to the public service organizations (Constitution, 1972). GO 
and NGO have been recruiting for a long from the launching their firms and equally treated. According to Global Gender Report (2010) $30 \%$ of women are holding the corporate positions. Attractive remunerative packages fascinated female in the corporate service. It has been observing that women are now involved in the service of the banking sector, telecom industries, airlines professionals, physician, journalism etc. Bangladesh is not an excluded. In the banking sector Bangladesh, many women are serving the public and private banks and reaching the top position. A study was conducted whether women employ in the managerial positions and presenting the women at senior managerial roles and suggested to include gender studies as discourses and practices (Anne and Kate, 2010). Another study, authors examined whether women employ gender capital in the management field and proposed the different ways in the presence of women in the senior managerial roles could shape contemporary management discourses and practices (Kamal and Amina, 2014). Another study (Afza and Newaz, 2008) examined the existence of glass ceiling in different industries and service sectors in Bangladesh. There are two questions raised regarding women: what are the formal and informal requirements for advancement women in the government services of Bangladesh? Do any of these requirements place women as disadvantage situation with respect to career advancement? The authors that women representation in civil service is in increasing trend but at the higher-level positions presence of women is far low, which is indicative of the existence of certain barriers to the advancement of women (Kabir et al., 2016; Kabir, 2014). In corporate women's position is just like a pyramid. Here huge portion of women are recruited at the entry level but few of them to reach the top. For instance, the Bangladesh Bank data showed that only one bank has so far set up childcare unit but other banks are ignoring it. Besides, 25 banks had not arranged any transport facilities for female staffs and only 9 banks initiated arranging awareness training on gender issue (Uddin, 2013). It has been observed by the studies and reports that the employment rate in the banking sector of Bangladesh declined to $12.23 \%$ in 2018 from $13.73 \%$ in the earlier year 2018 (Mehedi and Sumon, 2017). The ratio of female executives reaching higher positions shows a negligible figure found by BIBM study (www.dailyasianage.com/April 2017). Central Bank of Bangladesh (BB) officials stated that the women employees have not been by the new launched banks in the country (BB Official, 2017). Studies were conducted based on different issues of women and their status, socio-economic scenario. The main aim of the present study is to investigate the women's position in the banking industry (public and private) of Bangladesh. The study purposively selected the Rangpur City as survey area.

\section{Research Questions}

1. What are the present positions of women in the public and private banks?

2. What are drawbacks of women occupying the managerial positions in the banking sector?

\section{Objectives of the Study}

The main goal of the study is to investigate the present position of the female employees in the banking sector. The specific objectives are set as:

- To highlight the present position of male and female employees in the study, and

- To justify the gender position with receiving number of promotions for advancement.

\section{Data and Methods}

The study has been conducted on the basis of primary and secondary sources. There are around 1190 employees are serving the different banks in the study area. Primary data are collected through Likert's Five Point Scale (Agree $(A)=1$, Strongly Agree $(S A)=2$, Disagree $(D)=3$, Strongly Disagree $(\mathrm{SD})=4$, and Neutral $(\mathrm{N})=5$. A purposive sampling was used to gathering information from 185 male and 65 female employees $(\mathrm{N}=250)$ out of 65 branches of 41 different banks operating in Rangpur City. Questionnaire developed for examining the number in case of gender position in the respective banks. The $\chi^{2}$-test was used to test hypothesis. Secondary data are collected from the different journals, articles, publications, dailies, bank websites etc. to analysis the earlier literature. Survey was conducted in 2018 at Rangpur City, Bangladesh.

\section{Hypothesis: $H_{a}$ : There is an effect of promotion on women's position in the banks.}

\section{Results and Discussion}

It is evident that there is no bias for upgrading the male and female employees. The banking institutions are to follow the general qualifications, experiences, efficiency of the employees while taking promotional decision respective positions (Table 1). Female employees recognize that they have been treated equally regarding the gender bias. Banks consider female employees are the vital part as the corporate citizenship globally. Most of the male employees mean that they are treated equally without bias.

The Table 2 shows that total 557 employees work in the state-owned commercial banks whereas $464(83.30 \%)$ of male and $85(16.70 \%)$ of female as percentage. Elaborately 557 employees were in the service of 8 branches of Sonali Bank Limited, 4 branches of Janata Bank Limited, 5 branches of Agrani Bank Limited, 4 branches of Rupali Bank Limited, 1 branch of BASIC Bank Limited, and 1 branch of BDBL is operating in Rangpur City. 
Table 1: Demographic Composition $(\mathrm{N}=250)$, Field Survey

\begin{tabular}{|c|c|c|c|c|}
\hline \multicolumn{2}{|c|}{ Demographic profile } & \multirow{2}{*}{\begin{tabular}{|l|} 
Male $(\%)$ \\
$50(27.03 \%)$ \\
\end{tabular}} & \multirow{2}{*}{\begin{tabular}{|l|} 
Female $(\%)$ \\
$19(29.23 \%)$
\end{tabular}} & \multirow{2}{*}{\begin{tabular}{|c|} 
Observations on 1st column \\
It is being observed that male employees 185
\end{tabular}} \\
\hline \multirow{7}{*}{$\begin{array}{l}\text { (1.a) Age group } \\
\text { (year) } \\
\text { Ratio: } M=185 \\
F=65\end{array}$} & $25-30$ & & & \\
\hline & $31-35$ & $59(31.90 \%)$ & $32(49.23 \%)$ & \multirow{7}{*}{$\begin{array}{l}(74 \%) \text { are more than the female } 65(26 \%) \text {. The } \\
\text { average age of male and female employees is } \\
33.45 \text { years and } 32.92 \text { years respectively which } \\
\text { is more than the female employees (1.a). }\end{array}$} \\
\hline & $36-40$ & $34(18.38 \%)$ & $5(7.78 \%)$ & \\
\hline & $40-45$ & $12(6.48 \%)$ & $3(7.70 \%)$ & \\
\hline & $45-50$ & $10(5.41 \%)$ & $-(0)$ & \\
\hline & $50-55$ & $10(5.41 \%)$ & $4(6.45 \%)$ & \\
\hline & $55-60$ & $10(5.41 \%)$ & $2(3.08 \%)$ & \\
\hline Average age & Years & 33.45 & 32.92 & \\
\hline \multirow{2}{*}{$\begin{array}{l}\text { (1.b) Edu. } \\
\text { qualification }\end{array}$} & Bachelor & $46(24.87 \%)$ & $26(40 \%)$ & \multirow{2}{*}{$\begin{array}{l}\text { Bachelor and master degree ratio are about } \\
.25: 75 \text {, and } .40: .60(1 . b) \text {. }\end{array}$} \\
\hline & Master & $139(75.13 \%)$ & $39(60 \%)$ & \\
\hline \multirow{8}{*}{$\begin{array}{l}(1 . c) \text { Job } \\
\text { experience } \\
\text { (year) }\end{array}$} & $1-5$ & $89(48.10 \%)$ & $40(61.54 \%)$ & \multirow{8}{*}{$\begin{array}{l}\text { Serving with obtaining experience between } 1-5 \\
\text { years of the female employees is greater than the } \\
\text { male but in remaining other cases it is } \\
\text { exceptional that means greater than female } \\
\text { employees (1.c). }\end{array}$} \\
\hline & 6-10 & $44(23.78 \%)$ & $8(12.31 \%)$ & \\
\hline & $11-15$ & $13(7.02 \%)$ & $6(9.32 \%)$ & \\
\hline & $16-20$ & $8(4.32 \%)$ & 0 & \\
\hline & $21-25$ & $8(4.32 \%)$ & 0 & \\
\hline & $26-30$ & $10(5.40 \%)$ & $5(7.70 \%)$ & \\
\hline & $31-35$ & $11(5.95 \%)$ & $6(9.23 \%)$ & \\
\hline & $36-40$ & $2(1.08 \%)$ & 0 & \\
\hline \multirow{7}{*}{$\begin{array}{l}\text { (1.d) Number of } \\
\text { promotions } \\
\text { received }\end{array}$} & Nil & $93(50.28 \%)$ & $38(58.26 \%)$ & \multirow{7}{*}{$\begin{array}{l}\text { Both male and female employees received } \\
\text { promotion with equal basis. That means it is } \\
\text { being found that there is no difference between } \\
\text { male and female employees regarding } \\
\text { promotion and advancement (1.d). }\end{array}$} \\
\hline & One & $38(20.54 \%)$ & $11(16.92 \%)$ & \\
\hline & Two & $22(11.89 \%)$ & $8(12.31 \%)$ & \\
\hline & Three & $25(13.51 \%)$ & $4(6.15 \%)$ & \\
\hline & Four & $3(1.62 \%)$ & $1(1.54 \%)$ & \\
\hline & Five & $2(1.08 \%)$ & $2(3.08 \%)$ & \\
\hline & Six & $2(1.08 \%)$ & $1(1.54 \%)$ & \\
\hline \multirow{5}{*}{$\begin{array}{l}\text { (1.e) Obstacles to } \\
\text { advancement } \\
\text { (perception) }\end{array}$} & Agree & $10(5.41 \%)$ & $4(6.15 \%)$ & \multirow{5}{*}{$\begin{array}{l}\text { Female employees are recruited at the first line } \\
\text { level. Both of them are disagreed regarding } \\
\text { static barrier to women at advancement (1.e). }\end{array}$} \\
\hline & SA & 0 & 0 & \\
\hline & Disagree & $64(34.59 \%)$ & $21(32.31 \%)$ & \\
\hline & SD & $111(60.0 \%)$ & $40(61.54 \%)$ & \\
\hline & Neutral & 0 & 0 & \\
\hline
\end{tabular}

Source: Compiled from field survey 2018.

Table 2: Employee of different State -owned Commercial Banks (SOBs) in Rangpur City

\begin{tabular}{|l|l|l|l|}
\hline Name of the bank (branch) & Male & Female & Total \\
\hline 1. Sonali Bank Limited, (8) & $235(80.48 \%)$ & $57(19.52 \%)$ & 292 \\
\hline 2. Janata Bank Limited, (4) & $71(85.54 \%)$ & $12(14.46 \%)$ & 83 \\
\hline 3. Agrani Bank Ltd., (5) & $80(85.10 \%)$ & $14(14.90 \%)$ & 94 \\
\hline 4. Rupali Bank Ltd., (4) & $48(87.27 \%)$ & $6(12.73 \%)$ & 54 \\
\hline 5. BASIC Bank (1) & $19(86.36 \%)$ & $03(13.64 \%)$ & 22 \\
\hline 6. BDBL, (1) & $11(91.67 \%)$ & $1(8.33 \%)$ & 12 \\
\hline Total $=\mathrm{SL}_{1}-\mathrm{SL}_{6}(\mathbf{2 3}$ branches) & $\mathbf{4 6 4}(\mathbf{8 3 . 3 0 \%})$ & $\mathbf{9 3}(\mathbf{1 6 . 7 0 \%})$ & $\mathbf{5 5 7}$ \\
\hline
\end{tabular}

Table 3 shows that 526 employees have been in the service of 31 private commercial banks including one co-operative bank limited at 34 branches whereas $455(86.50 \%)$ of male and $71(13.50 \%)$ of female.

From Table 4 it is being observed that total number employees are in the service of the specialized bank at the study area whereas $86.92 \%$ of male and $13.08 \%$ of female.
Table 5 confirmations that 41 different Banks at 65 branches of the respective Bank of which $80.48 \%$ male and $19.52 \%$ female employees are working in the state-owned commercial banks and its 23 branches, and $86.5 \%$ of male and $13.5 \%$ of female employees are in the service at private commercial banks and its 35 branches, and remaining $86.92 \%$ of male and $13.08 \%$ of female employees have been serving at 7 the specialized banks of the study area. 
Table 3: Employees in Private Commercial Banks (PCBs) in Rangpur City (Total=526)

\begin{tabular}{|c|c|c|c|c|c|}
\hline Banks (br.) & Male & Female & Banks & Male & Female \\
\hline 1. PBL (3) & $30(66.67 \%)$ & $15(33.33 \%)$ & 17. AAIBL & $7(77.78 \%)$ & $2(22.22 \%)$ \\
\hline 2. UBL (2) & $24(80.71 \%)$ & $4(14.29 \%)$ & 18. Premier & $8(80 \%)$ & $2(20 \%)$ \\
\hline 3. SIBL & $13(92.86 \%)$ & $1(7.14 \%)$ & 19. SIBL & $18(94.74 \%)$ & $1(5.26 \%)$ \\
\hline 4. UCBL & $11(84.62 \%)$ & $2(15.38 \%)$ & 20. ONE & $10(91.9 \%)$ & $1(8.1 \%)$ \\
\hline 5. NCC & $11(84.62 \%)$ & $2(15.38 \%)$ & 21. Jamuna & $15(78.95 \%)$ & $4(21.05 \%)$ \\
\hline 6. MTBL & $10(91.91 \%)$ & $1(9.1 \%)$ & 22.SBACBL & $9(100 \%)$ & $0(0.0 \%)$ \\
\hline 7. DBL & $9(90 \%)$ & $1(10 \%)$ & 23. Southeast & $12(92.31 \%)$ & $1(7.69 \%)$ \\
\hline 8. PRIME & $11(91.67 \%)$ & $1(8.33 \%)$ & 24. Trust & $10(100 \%)$ & $0(0 \%)$ \\
\hline 9. EXIM & $12(80 \%)$ & $3(20 \%)$ & 25. BRAC & $12(80 \%)$ & $3(20 \%)$ \\
\hline 10. IFIC & $9(75 \%)$ & $3(25 \%)$ & 26.AB Bank & $9(75 \%)$ & $3(25 \%)$ \\
\hline 11. IBBL (2) & $87(90.62 \%)$ & $9(9.38 \%)$ & 27. The City & $9(81.82 \%)$ & $2(18.18 \%)$ \\
\hline 12. NBL & $19(95 \%)$ & $1(5 \%)$ & 28. Standard & $13(100 \%)$ & $0(0 \%)$ \\
\hline 13. Bank Asia & $7(100 \%)$ & $0(0.0 \%)$ & 29. DMC & $20(95.24 \%)$ & $1(4.76 \%)$ \\
\hline 14. NRBC & $5(83.33 \%)$ & $1(16.67 \%)$ & 30. FSIBL & $09(90.91 \%)$ & $2(90.91 \%)$ \\
\hline 15. MBL & $13(92.86 \%)$ & $1(7.14 \%)$ & 31. DBBL & $14(87.5 \%)$ & $2(12.5 \%)$ \\
\hline 16. Eastern & $10(90.91 \%)$ & $1(9.09 \%)$ & Total & $455(86.5 \%)$ & $71(13.5 \%)$ \\
\hline
\end{tabular}

Source: Field Survey 2018.

Table 4: Employees in Specialized Banks (SPBs), Rangpur City

\begin{tabular}{|l|l|l|l|}
\hline Name of Bank & Male & Female & Total \\
\hline 1. RAKUB (4 branches) & $45(83.33 \%)$ & $09(16.67 \%)$ & 54 \\
\hline 2. Karmasangsthan Bank & $06(85.71 \%)$ & $01(14.29 \%)$ & 07 \\
\hline 3. Prabasi Kallan Bank & $04(80 \%)$ & $01(20 \%)$ & 05 \\
\hline 4. Grameen Bank & $38(92.68 \%)$ & $03(7.32 \%)$ & 41 \\
\hline Total = $(1+2+3+4)$ & $\mathbf{9 3}(\mathbf{8 6 . 9 2 \% )}$ & $\mathbf{1 4}(\mathbf{1 3 . 0 8 \%})$ & 107 \\
\hline
\end{tabular}

Source: Field Survey 2018.

Table 5: Overall distribution of total employees of 3 categories banks in Rangpur City

\begin{tabular}{|l|c|l|l|l|}
\hline Name of the Bank & Total & Male & Male & Female \\
\hline SOBs (23 branches) & 06 & $557(46.8 \%)$ & $464(80.48 \%)$ & $93(19.52 \%)$ \\
\hline PCBs (35 branches) & 31 & $526(44.2 \%)$ & $455(86.5 \%)$ & $71(13.50 \%)$ \\
\hline SPBs (7 branches) & 04 & $107(8.99 \%)$ & $93(86.92 \%)$ & $14(13.08 \%)$ \\
\hline Employees of 65 branches & $\mathbf{4 1}$ & $\mathbf{1 1 9 0}(\mathbf{1 0 0 \%})$ & $\mathbf{1 0 1 2}(\mathbf{8 5 \%})$ & $\mathbf{1 7 8 ( 1 5 \% )}$ \\
\hline
\end{tabular}

Source: Field Survey 2018.

Table 6 shows that female employees are less than the male employees serving the banking sector at the study field. Female employees are holding the $25 \%$ of female at entry level, which is the maximum number. Holding the position at upper levels by the female employees such as AAVP, AGM, DGM, GM etc. are not found due to fewer number with compared to the male employees.

\section{Analysis of hypothesis}

Due to some of the values in the Demographic Table 1 are less than 5 so all the values are multiplied by 5 for constructing the following Cross Table 7 to test the hypothesis. Chi- Square test applied to test dependency between gender of the employee and number of promotions received and gender of the participants 
$H_{a}$ : There is an effect of promotion on women's position in the banks.

It is found from Table 8 that $\chi^{2}$ calculated value is 22.366 . At $5 \%$ level of significance and 6 degree of freedom the $\chi^{2}$ table value is 12.60 and the calculated value is 22.366 . Here the calculated value is more than the table value. Therefore, the null hypothesis is rejected and alternative hypothesis supported. Therefore, there is a highly relationship between gender position and number of getting promotion. It is confirmed that there is an impact of up gradation on gender position.

Table 6: Profile of holding positions of the 250 respondents (compiled from field survey)

\begin{tabular}{|c|c|c|c|}
\hline Position (n=250; 185:65) & Male (M) & Female (F) & Executive Level \\
\hline General Manager (GM) & $1(0.54 \%)$ & - & \multirow{4}{*}{$\begin{array}{c}\text { Senior Executive level o\% } \\
\text { of female } \\
2.8 \%(\mathrm{M}) \& 0 \%(\mathrm{~F})\end{array}$} \\
\hline Deputy General Manager (DGM) & $1(0.54 \%)$ & - & \\
\hline Assistant General Manager (AGM) & $1(0.54 \%)$ & - & \\
\hline Sr. Assistant Vice President (SAVP) & $4(2.16 \%)$ & - & \\
\hline Senior Principal Officer (SPO) & $15(8.11 \%)$ & $1(1.54 \%)$ & \multirow{2}{*}{$\begin{array}{c}\text { Executive } \\
9.2 \%(\mathrm{M}) \& 1.2 \%(\mathrm{~F})\end{array}$} \\
\hline Principal Officer (PO) & $8(4.32 \%)$ & $2(3.08 \%)$ & \\
\hline Management Trainee Officer (MTO) & $5(3.70 \%)$ & - & \multirow{5}{*}{$\begin{array}{l}\text { Entry Level Executive } \\
62 \%(\mathrm{M}) \& 25 \%(\mathrm{~F})\end{array}$} \\
\hline Senior Officer (SO) & $63(34.05 \%)$ & $20(30.70 \%)$ & \\
\hline Probationary Officer (PO) & $3(1.62 \%)$ & - & \\
\hline Officer & $47(25.41 \%)$ & $10(15.38 \%)$ & \\
\hline Junior Officer (JO) & $37(20.0 \%)$ & $32(49.23 \%)$ & \\
\hline
\end{tabular}

Source: Field Survey 2018.

Table 7: Cross Table containing data on the number of promotions* (developed from Table 1).

\begin{tabular}{|c|c|c|c|c|}
\hline $\begin{array}{l}\text { Number of } \\
\text { promotions }\end{array}$ & Male & Female & $\begin{array}{l}\text { Row } \\
\text { (RT) }\end{array}$ & Measurement \\
\hline $\begin{array}{l}\text { Not given } \\
\text { promotion }\end{array}$ & 465 & 190 & 655 & \multirow{8}{*}{$\begin{array}{l}\text { Level of significance } 5 \% \text {, Degree of freedom }(\mathrm{df}):(2-1) \times(7- \\
\text { 1) }=6 \text {, } \\
\text { Chi-Square Test }\left(\chi^{2}\right)=\sum(\mathrm{O}-\mathrm{E})^{2} / \mathrm{E} \text {. Where, O= Observed } \\
\text { Value, E=Expected Value }=(\text { Row Total } \times \text { Column Total }) / \\
\text { Grand Total }(\text { Table } 7) .\end{array}$} \\
\hline One time & 190 & 55 & 245 & \\
\hline Two times & 110 & 40 & 150 & \\
\hline Three times & 125 & 20 & 145 & \\
\hline Four times & 15 & 5 & 20 & \\
\hline Five times & 10 & 10 & 20 & \\
\hline Six times & 10 & 5 & 15 & \\
\hline $\begin{array}{l}\text { Column Total } \\
\text { (CT) \& (RT) }\end{array}$ & 925 & 325 & 1250 & \\
\hline
\end{tabular}


Table 8: Calculation for $\chi^{2}$ value (constructed from Table 7)

\begin{tabular}{|l|l|l|l|l|}
\hline $\mathbf{O}$ & $\mathbf{E}$ & $\mathbf{O - E}$ & $(\mathbf{O}-\mathbf{E})^{\mathbf{2}}$ & $(\mathbf{O - E})^{2} / \mathbf{E}$ \\
\hline 465 & 484.70 & -19.70 & 388.09 & 0.8006 \\
\hline 190 & 170.30 & 19.70 & 388.09 & 2.2788 \\
\hline 190 & 181.30 & 8.70 & 75.69 & 0.4174 \\
\hline 55 & 63.70 & -8.70 & 75.69 & 1.1882 \\
\hline 110 & 111 & -1 & 1 & 0.0090 \\
\hline 40 & 39 & 1 & 1 & 0.0256 \\
\hline 125 & 107.30 & 17.70 & 313.29 & 2.9197 \\
\hline 20 & 37.70 & -17.70 & 313.29 & 8.3100 \\
\hline 15 & 14.8 & .20 & 0.04 & 0.0027 \\
\hline 5 & 5.2 & -.20 & 0.04 & 0.0076 \\
\hline 10 & 14.8 & -4.80 & 23.04 & 1.5567 \\
\hline 10 & 5.2 & 4.80 & 23.04 & 4.4307 \\
\hline 10 & 11.1 & -1.10 & 1.21 & 0.1090 \\
\hline 5 & 3.90 & 1.10 & 1.21 & 0.3102 \\
\hline & $\sum(\mathbf{O}-\mathbf{E})^{2} / \mathbf{E}=\mathbf{2 2 . 3 6 6}$ & \\
\hline
\end{tabular}

\section{Conclusion}

Presently it is shown that Bangladeshi women are career oriented. Bangladesh has given attention to progress the women empowerment. Lucrative salary packages, congenial working environment along with other opportunities are attracted women's attachment in the corporate service. Today they are now in the service of the banks, telecom industries, airlines professionals, physician, journalism etc. Definitely it is a desired achievement. While doing decisional and operational performances the banks are to consider the welfare of the organization itself and this is why banking organizations recruit the employees those who have ability to do or to show their efficiency and talent. In Bangladesh we could see that the banks are trying to ensure the equal importance as per the policy. Women are promoted as they can. It is done in every sector of the country. The study found that there is gender bias in the banks. It is enhanced to eliminate existing discrimination between men and women (NWD, 2011). Women are recruited and got promotion on due at the lower and middle levels but not at the top level. At the time of recruitment women candidates are few than the male candidates. If this number may be the same as the male candidates it could be overcome. Today women know better how they fight the challenges. In recent women represent themselves half of the world's workforce prospect comprises of $49.6 \%$ women. If it is then $26 \%$ of the contribution of income will be added in GDP by 2025 . It is expected women participation in the job market has been increased since it was $4 \%$ in 1974 but it is observed that $35.6 \%$ in 2016 (https://idlc.com/). Now by keeping pace with the male employees, aside mental stigma and stereotype mentality, women are able to go forward with strong willingness and confidence. The study is done based on a limited location. The researcher thinks that this could be made on a large scale through taking furthermore study contributing to take more initiatives.

\section{Authors' Contribution}

M A Rahman, corresponding author planned and anlyzed the research article, M R Azam Khan developed the structure and review the context of the paper. Final version of the research paper has been recognized by authors.

\section{Conflict of Interest}

The author has declared that there is no engagement of interest with the existing article and its publication.

\section{Acknowledgement}

Authors are grateful to the employees of the respective bank branches operating in the Rangpur City of Bangladesh since they provided information with full cooperation and connection for the study. The authors also like to give special thanks to Mr. H R Basunia (MBA Student, Management Studies, BRUR) for his co-operation for collecting data.

\section{References}

Afza RS and Newaz MK (2008) Factors Determining the Presence of Glass ceiling and Influencing Women Career Advancement in Bangladesh. BRAC University Journal 5(1): 85-92.

Anne RS and Kate H (2010) Management, Women and Gender Capital. Gender, Work \& Organization, and special Issue: Women and Men in Management: Issues for $21^{\text {st }}$ Century 17: $547-566$.

Aricle 29 (2), "No citizen shall, pn grounds only of religion, race, caste, sex or place of birth, be ineligible for, or discriminated against in respect of, any employment or office in the service of the Republic". 
BB Official (2017) "Many new banks are not recruiting women employees following Bangladesh Bank's order. That's why the ratio of women bankers is not increasing." The Asian Age, 26 April.

Gender Policy (2014) $3^{\text {rd }}$ Edition, RDRS Bangladesh, Sept. 2014: 8-11.

Internship Report (2016, 2017) Department of Management Studies, BRUR. https://idlc.com/mbr/article.php?id=203.

Kabir LS, Haque M. and Tawfique MMS (2016) Bashing the Glass Ceiling for the Women in Bangladesh Civil Service: An Overview. 24 ${ }^{\text {th }}$ World Congress of Political Science, July 23-28, Istanbul, Turkey.

Kabir SJ (2014) The Impact of Gender Differences on the Conflict Management Styles of Managers in Bangladesh: An Analysis. Newcastle upon Tyne, UK: Cambridge Scholars Publishing.
Kamal RD and Amina S (2014) Gender Gap and Present State of Working Women in Corporate Arena: An Overview of Bangladesh Perspective. Research on Humanities and Social Sciences, 4(10): 82-88.

Mehedi F and Sumon RH (2017) Women in the Banking Sector Fall Far Behind Men. Observer, 26 April.

NWD (2011) Objectives of National Women Development Policy.

The Constitution (1972) "There shall be equality of opportunity for all citizens in respect of employment or office in the service of the Republic". The Constitution of the People's Republic of Bangladesh, Act No. of 1972: Article 29 (1).

Uddin Z (2013) Gender Discrimination Persist in Bank. DC: New Age, June 18.

UNDP (1993) Report on Public administration sector study in Bangladesh. Dhaka: UNDP. 